\title{
The Challenges of an Ethnic- democracy: Populism, Netanyahu and Israel's Path
}

\begin{abstract}
Soon to become Israel's longest serving Prime Minister, Benjamin Netanyahu's fourth government is regarded as the most right-wing coalition in Israeli history. While populism is on the rise worldwide, Netanyahu has been in power intermittently since the 90 's - utilising a particular kind of populism articulated by Dani Filc (2009) - post-populism - to remain in power. Examining Israel's special and delicate political status as an ethnic-democracy, this chapter concludes that the current government is promoting rhetoric and policy which entail the risk of defying the balance between Israel's Jewish-ethnic character, its obligation to Democratic values and the integrity of its ethnic and political minorities. In election campaigns and attempts to secure political capital, as well as in everyday legislation, the current government has directly and indirectly targeted minorities, left-wing opposition and civil rights group. Exclusionary nationalistic rhetoric, a tool vastly used by right wing populists worldwide in the US, France, the UK and others, has become a common commodity in the Israeli right's toolbox. With the balance still preserved, Israel's democracy is facing grave challenges ahead - and as Israel's president Rubi Rivlin said, the Israeli society must ensure it reaches these challenges prepared.
\end{abstract}

\section{Daniel Gal ${ }^{1}$}

1 Daniel Gal received a bachelor degree in European Studies at Maastricht University in 2017.

Contact: danielgal@gmail.com 


\section{Introduction}

Populism, a term that does not have one all-encompassing theoretical conceptualisation, has seen a global resurgence in recent years. Once dismissed as "the paranoid style of politics" (Hofstadter, 1967), from the United States, through Latin America, Western and Eastern Europe, Asia - and the Middle East - leaders depicted as Populist, through different points of view, have been able to promote their ideas - and gain political ground in many countries. To name a few, it is the victory of Donald Trump in the 2016 US elections, Britain's 'Leave' vote in the EU referendum and Marine Le Pen's far reaching, yet unsuccessful, French presidential bid. With the greater strength enjoyed by Right- and Left-wing populist parties in other European countries - many are left wondering of what is to come on this political front. In Europe alone, populist parties have more than doubled their average share of the vote on both the National and European levels since the 1960s, also tripling the share of their seats (Inglehart \& Norris, 2016; QUARTZ, 2016).

In the context of the aforementioned trend, it is interesting to look not only at populism and at its causes - but also to examine, past and present, other forms of Populist leadership - some of which have been in power decades before the new wave gained any momentum. Following this conviction, this chapter will examine the populist leadership of Benjamin Netanyahu, Israel's longest continuing tenure serving Prime Minister (Kenig, 2016) (beating the record of the 'founding father' of the nation, David Ben-Gurion), leading the Israeli Right-wing Likud party. The Likud, coming to power for the first time in the 1977 historical national elections, won that race led by its first claimed Populist leader - Menachem Begin. Since this initial success, the party was headed by other leaders - more or less successfully - until Netanyahu's 1996 victory following the assassination of Prime Minister Yitzhak Rabin. Though not consecutively in power since 1996, Netanyahu has come to be one of Israel's most prominent political figures - playing a major role in the Israeli political system almost consecutively since his first term in office (Tahroor, 2012).

Netanyahu's character and depiction as a populist leader is not unique, yet it is different from other, 'classic' populist leaders - domestically and worldwide. Weiss-Yaniv and Tenenboim-Weinblat stress that "while there appears to be no shortage of populist manifestations in Israel's short political history, there is surprisingly little research on populism in Israel" (2016). While populist politics very much exists in Israel, from the far-right through the center to the far-left, a sound account of these is not available. It is worth mentioning that there has been quite comprehensive work done regarding extreme-right politics in Israel, a camp which the Netanyahu's Likud party is traditionally not considered a part of.

Dani Filc has produced the most comprehensive account of Israeli populism (though dealing almost exclusively with Right wing populist movements). His main body of research - the populist face of the Likud party from Begin to Netanyahu and until current time - depicts Netanyahu's populism as post-populism. The latter refers to successful populist leaders who have managed to retain popular support while enacting broad neo-liberal policies of which popular sectors are the main victims. Not alone in this club, other postpopulist leaders can include, for example, Carlos Menem of Argentina and Abdallah Buccaram of Ecuador - all characterised by popular support while 
leading exclusionary neo-liberal economic agendas. Filc describes Netanyahu's post-populism as constructed of three pillars: the (1) Material dimension in the form of economic neo-liberalism, the (2) Political dimension in the form of an authoritarian notion of politics and, most importantly for this study, the (3) Symbolic dimension in the form of conservative nationalism (2009).

It is the symbolic dimension that will be the focus in this chapter. For matters of scope, relevance and focus - assessing one of the three pillars will allow a better understanding of a major characteristics of populism worldwide - and one that we claim Netanyahu has utilised to a large extent in the last decades - conservative nationalism. In this sense, the dimension includes rhetoric driven by xenophobic, exclusionary ethnic nationalism as well as antielite sentiment against the academia, the media and the Left wing of the political map. In accounts of Netanyahu's campaigns thus far, he has mobilised these notions time and again to gain ground (Filc, 2009).

It is not enough to understand the politics of Netanyahu's government solely through the lens of populism and his depiction as a post-populist leader. Namely, it is evident that while the Likud party has traditionally been depicted as 'center-right' (The Economist, 2015), more similar to the British Conservative party, the effect exerted by radical right elements, both from within the Likud party and externally to it, has caused a shift to the right on a 'camp wide' basis, where the coalition and political considerations are pushing policy in an ever more extreme direction. It is safe to conclude, as stated by Secretary of State John Kerry: ". . . his [Netanyahu's] current coalition is the most right-wing in Israeli history, with an agenda driven by the most extreme elements" (Washington Examiner, December 28, 2016).

Going beyond the campaign, events demonstrating nationalism and extreme-right sentiment will be examined through the concepts of Uri Ram (2003) and Sammy Samooha (2002), described below. As Netanyahu's current coalition is considered the most right-wing in Israeli history, this chapter wishes to examine a number of policies and rhetoric employed by the Likud party in order to assess the balance between the civil state emphasis and the Jewish Nationalism emphasis of the state - as they are conveyed in the events described.

Through these two lenses, and following the characteristics of the symbolic face of post-populism, this chapter will claim that the 2015 General Elections in Israel and the aftermath under Netanyahu's new government (Israel's 34th, Netanyahu's 4th) have been characterised by exclusionary ethnic rhetoric and policy. Connecting these with Smooha's ethnic democracy and Ram's balance between the civil state and Jewish nationalism - this chapter will shed light on the direction showcased by the aforementioned rhetoric. Namely, it will stress that the current government leans toward an extreme nationalistic emphasis with features of ethnic democracy and following the neo-Zionist path at the expense of the Arab minority in Israel and left-wing opposition. The latter will be shown through a variety of tools, as discourse, legislation and other political tools emphasise how the 'other' - be it the Arab population or the Leftist elite - has become a central issue used in preserving popular support.

The analysis of this claimed escalation will be conducted by surveying main issues, especially those which received wide media attention, from the 2015 election campaign until recently. First, it will compare the 2009 symbolic pillar, as depicted by Filc (2009), with key Likud party campaign events of the 2015 elections. Second, it will survey a number of issues promoted by the 
current government. Surveying Netanyahu's own words, the actions of his top political allies (mainly focusing on those from within the Likud party), I believe that the reader can gain an understanding of the current scope of use of the symbolic dimension of populism - connecting to the global trend and the words of other populist leaders worldwide. It will also become evident that while receiving the title symbolic - the use of these tools does not stop at the rhetorical level, but is also translated into policy, government and civil action.

\section{Israeli Identity - The Challenge of an Ethnic Democracy}

It is important to stress that the debate on Israeli identity poses challenges that may not be found in other nations and democracies - this is due to the nature of the Zionist project as a melting pot of religious, ethnic and national identities. The notion of Israel as a Jewish AND Democratic state poses a significant challenge to Israeli identity questions. The very idea of creating a hybrid between the religious and national spheres of a nation-state, transformed into a national identity through the project of Zionism, leaves some people wondering, at times in unease (Stern, 2017, p.4).

In order to gain a good introduction to this debate, which will not be elaborated on further due to its complexity as a 'stand-alone' issue, it is best to look at the concept of 'Ethnic Democracy' - as introduced by Sammy Smooha (1989). Applicable to states as Estonia, Latvia and Slovakia - as well as Israel - an Ethnic Democracy is one that is considered democratic while holding a 'strong ethnic bias', which differentiates them from other forms and principles of democracy. While these could be casted aside as none democratic, or fit a 'stretched' concept of democracy, their conceptualisation as 'ethnic democracies' helps set them apart.

The features of an Ethnic Democracy, namely those applicable to Israel, were coined by Smooha (2002). It is driven by an ideology of Ethnic Nationalism, declaring a population as an ethnic nation sharing blood ties, language and culture - all of which belong to a territory, an 'exclusive homeland', where it erects its state in which it exercises its right for selfdetermination. Rather than the citizenry, it is the ethnic state that shapes symbols, laws and policies to benefit the majority - while making a distinction between members and non-members of the ethnic nation. The latter are considered as 'others' and at times seen as a threat to the integrity of the ethnic nation. The threat factor is reinforced by the ethnic affiliation of the minority, while the external affiliated group is an enemy (Smooha, 2002, p. 478-9). The political system is democratic, ensuring the rights of individuals, as well as collective rights of the minority. Minorities are allowed to strive for equal rights without fear of repression and are allowed to join coalition groups with the majority. Yet, the democratic character of the system still entails non-members enjoying rights that are inferior, while being discriminated against by the state. Functioning as a 'defensive democracy', it is a political system which deters "highly menacing groups". According to the author, "Ethnic democracy suffers from an inherent contradiction between ethnic ascendance and civic equality" (p. 478). 
It is the latter issue, in turn, that has evolved into the vast debate about Israeli identity - including the prevalence of the religious identity, the question of the fine lines drawn between both worlds and the consolidation of the fact that not all Israelis are Jewish - but rather non-members of the prevailing ethnic-Jewish group. It is also important to note one of Smooha's (2002) conditions for stability of the ethnic state, one that will be revisited later in this chapter: "condition is a majority's continued sense of threat" (p. 479).

In his account of Israeli politics and identity, Uri Ram (2003) maps the Israeli political identity and its evolution over time. In short, Ram stresses the evolution of Israeli national identity from a 'homogenised Nation-State' to one in which many complex attitudes toward identity, fuelled by modernisation, globalisation and the local reactions to these trends, compete for dominance.

As Hobsbawm (1990) has stressed, at the end of the 20th century the tension between pre-nationalism and nationalism were no longer the prevailing topics. Current times, defined by globalisation trends, ushered in a new tension: post-nationalism and neo-nationalism (as cited in Ram, 2003).

Ram claims that until the 1970's, the core of political identity in Israel was controlled by the nation-state. As the 'hegemony' of the old founding elite gave way not to a new central hegemony of the new 'regime', but rather to a polarised situation between the civil pole and the national pole - both derived as a response to globalisation trends. The former is titled the post-Zionist pole while the latter is titled the neo-Zionist pole. (Ram, 2003, p. 499) It is in the area between these two where the political tension, what Ram calls 'political noise', of our time resides. For the matter of context in the greater debate about globalisation and identity, this cleavage can be compared to the tension between the 'global' and the 'local' on a general world scale (as witnessed in political debates throughout the West, and beyond) - the global being the postZionist pole, and the local the neo-Zionist pole, as explained below.

Connecting to Smooha's discussion of an Ethnic-Democracy, the importance of this tension to the Israeli case lies between the Jewish and Democratic faces of the state. Under a constant need for consolidation and balance between the two, the tension is between neo-Zionism - leaning toward the Jewish notion - and post-Zionism - leaning toward the democratic notion. The tension is manifested by one side leaning toward the ethnic, national Jewish political culture as the other moves between its democratic, liberal political culture while preserving the national identity of the Jewish state (Ram, p. 502). Published in 2003, at the height of the second Palestinian uprising (referred to as 'the second Intifada (Arabic for 'Uprising')', Ram finishes his analysis by offering scenarios for the evolution of identity and the connection between State and Nationality in the early 2000's. Firstly presented is a post-Zionist definition of identity, in which multiple 'national identities' are recognised and the civil state prevails. Second, a neo-Zionist scenario is presented in which Jewish Nationalism prevails, the state is stripped from its Liberal appearances and its ethno-national definition is strengthened. Lastly, the competition between the Civil, more liberal principle and the National, ethnic one will remain undecided for a while - "leaving the political system unstable and Israel at the verge of internal and external wars" (p. 505).

Although a politician himself, a former ally and current opposition of Netanyahu, former Prime Minister and Chief of Staff of the Israel Defense Forces, Ehud Barak - a prominent security and political figure in Israel - 
managed to put Ram's scenarios in an interesting perspective, more than ten years later:

Netanyahu, for years, him and Lieberman [Avigdor Lieberman, current minister of Defense], are taming the public to look at reality through two main questions: What are you first? Israeli or Jewish? If you are Israeli first, you are on the left wing. If you are Jewish first, you are on the right wing. Second question: Do you love Arabs or hate Arabs? If you love Arabs, you are left wing. No matter what 'loves' means. If you hate Arabs - you are right wing. As long as the opposition continues to accept the prism that these are the two relevant questions - the right wing will remain in power. (2017, March 18)

\section{Populism - Inclusive and Exclusionary Strands}

While other scholars have conducted extensive research on extreme right-wing parties in Israel, many of which defined as Populist (Ram, 2003; Filc, 2009; Peri, 2004) it is the theoretical contribution of Dani Filc which addresses the Likud party in the most comprehensive way. Filc $(2009,2011)$ constructs a depiction of Netanyahu as a post-populist, as well as examining the earlier stages of Likud lead populism; Menachem Begin's leadership, the creation of a Likud habitus and more. Also included in this book are parties 'Shas', an ultraorthodox religious party and 'Yisrael Beitenu' (Israel our Home), considered a more extreme and nationalistic party (Filc, 2009).

Acknowledging that Populism is a "contested term", Filc structures his work by first offering a perspective on populism as a "family of movements or parties" that appear, and flourish, where the prevailing conflicts are centered around the inclusion/exclusion of social groups (2009, p.2-3). This is an important concept constructed by Filc, and one that aids in understanding the complexity of post-populism.

\subsection{Populism - Inclusive and Exclusionary strands}

Paul Taggart credits Margaret Canovan with the "most ambitious attempt to get to grips with populism" (2000, p. 18). Canovan's 1981 "Populism" indeed mapped a comprehensive 'family' of a number of sub-groups of populism, all of which share some common features - namely 'the people' as the central entity and anti-elitism - while maintaining differences. Yet, both Taggart and Filc acknowledge the shortcomings of Canovan's categorisation as too wide, limiting the capability to analyse a specific populist phenomenon. Acknowledging the importance of conceptualisation of Populism as a "family of phenomena", Filc (2009) suggests sharpening this notion with a typology dividing Populism into two strands: Inclusive and Exclusionary populism. Firstly, four similarities are depicted: 1) a means for social groups to actively become politically active 2 ) appeal to the people as the centre 3 ) both intertwine three meanings of the word people as explained by Hermet (2001) and 4) both include a leader figure that 'embodies the people' (2009). Hermet's notion of the different meaning of the word 'people' is important as in different mixes these constitute the two strands of aforementioned populism. People can mean the entire nation, regardless of class divisions, "as synonymous with the 
plebs (ordinary citizen, distinguished from the elite)" (2001, p.12) or an organic, ethno-cultural unit, or the volk. Both strands include all three meanings, while Inclusive emphasises the people as plebeians and Exclusionary emphasises the ethno-cultural grouping of the people. Inclusive populism can be explained as "an alternative hegemonic project by and through which subordinate and excluded groups become political subjects that oppose the dominant bloc" (Filc, 2009, p. 13). This process of inclusion incorporates material inclusion (by improving the "material conditions" of the group), symbolic inclusion (by placing the ones excluded as an inherent part of the common "we", employing 'us vs. them' rhetoric) and political inclusion (the excluded become an "active collective political subject" and gain access to political power). Exclusionary populism "emerges in societies where social transformations threaten the identity of certain social sectors" (p. 15) and often represents radical right-wing movements. Seeking to protect the dominant identity, the common "we" and in response to a "rapidly changing world", exclusionary groups exclude the 'other'. In this form, exclusion is the tool mobilised to ensure the collective identity, by an "active process" perceived to be the "condition for the preservation of the threatened subject" (p. 16). Similarly, the process of exclusion incorporates material exclusion (achieved by excluding weaker social groups to appease the majority), symbolic exclusion (discourse depicting a 'common past' or 'shared reality' that does not include ethnic minorities or immigrants) and political exclusion (implementation of policies that are designed to exclude weak or marginal groups).

\subsection{First Signs of Populism - Begin's Inclusive Populism}

From the roots of the Zionist movement until 1977, the leading political power in Israel was the Israeli Labour party, constructing the "ethno-republican hegemonic model" that combined nation building with collectivist common good. The division in Israel was not signified by class but rather by ethnonational and ideological differences. Comprised by European-origin Jews, this group led the hegemonic project of nation building combining capitalist market economy with an extremely strong public sector. The latter included a central state institution, the General Workers Union, which became a huge factor in the market representing over 30\% of GDP by 1970.

Building an ethos, the group comprising the Labor movement saw themselves as the 'pioneers', creating an ethno-national and political "system of concentric circles of belonging" (Filc, 2009, p. 20). Thus, at this point of history, two groups were seen as 'excluded' through an ethno-national lens: the Palestinian-Arab minority lacked group rights and was heavily segregated by the system. Another group, important for this stage of the review, was the Mizrahim (Jewish immigrant from Arab countries, as opposed to EuropeanJews). The latter, although Jewish, were "part of the common 'we' but occupied a subaltern position", excluded from the ruling hegemonic entity and almost ignored as an independent political power. In a recently released film discussing the systematic exclusion of Mizrahim immigrants to Israel, a quote of Geyora Yoseftal, then the head of the Immigrant Assimilation department of the Jewish Agency, demonstrates the depiction of these immigrants in the eyes of the founding

elite:

There is a feeling of an immigration of a lesser moral compass, a 
lesser social level . . . that can bring the state to the depths of a Levantine society, at the same low-point as the people in the region. (Salah, this is The State of Israel, 2017) Another excluded group was the Israeli nationalist right. Though led by European-Jews and adopting the European nationalist right characteristic, this party failed to achieve access until its leader in the 1970's transformed it into an inclusive movement for the Mizrahim - creating a habitus that will continue to

this

day.

A few attributes render Herut/Likud a populist movement: view of the people as the source of virtue, anti-elitism, a populist notion of democracy, and anti-socialism (instead of anti-liberalism).

In the first incarnation as a populist movement, Likud populism was Inclusive in that it included Mizrahim, not Israeli-Arabs. Filc (2009) divides dimensions of inclusion in order to break down its different aspects: symbolic, political and material.

\subsection{Symbolic Inclusion (and Exclusion)}

The focus of this chapter, the use of the symbolic dimension by the inclusive populist Likud, was constructed on the basis of the exclusion of the Mizrahim. Begin identified this and utilised the populist tool of the people in order to create an inclusive atmosphere. Going beyond the commonly used Israeli term, Begin used the rhetoric of the Jewish people - as a whole - to create a space in which all Jews are included. Speaking to the long history of the Jewish people, namely to their suffering, persecution and sacrifice across the globe, he took away the distinction between the 'fathers of the nation' and the 'newcomers', depicting a single timeline in which all Jewish people are an active part of the national determination that came to be the State of Israel. Pedahzur states that this latter idea will continue to play a central role in Israeli society in the form of a "continuous sense of collective anxiety" (2012, p. 12), fuelled later by constant wars and tension with Israel's Arab neighbours.

It is crucial to note that in order to make place for this inclusion, the further exclusion of Israeli-Arabs (ethnically Palestinian) was promoted "closing the door to the future inclusion of Israeli-Arabs" (Filc, 2009, p. 31). This further exclusion will be carefully preserved and promoted in the later incarnation of Likud populism, as the Mizrahim will, to a large extent, already enjoy a status of 'included', through Begins's efforts to include them into a new "we" (p. 35).

\subsection{Material and Political Inclusion}

On the material front, the influence remained small as long as labour was in power. Yet, following a liberal economic platform, Likud promised "federal public services for the entire population" ( $p .36$ ) and chose social policies designed to curb the exclusion of Mizrahim. More importantly, Begin's efforts lead to the successful inclusion of Mizrahim on the political sphere, allowing the group to become a political subject. Likud and Begin were the catalyzers, with support for them bringing about Mizrahi leadership, entrance of Mizrahim to the political institutions and most importantly - formation of the group as one with a unified political voice and transforming Likud into part of their identity (p. 42). 


\subsection{Post-populism - preserving the Symbolic Pillar}

Post-populism is a rather rare and complex phenomenon as it entails an inherent contradiction. While the Likud party (similar to regimes in Argentina, Ecuador and others) has been the most extreme promoter of neo-liberal economic policies, it still enjoys the immense support of the popular classes the very classes that are "the model's main victims" (Filc, p. 55).

In an attempt to consolidate this contradiction, a number of authors have stated manipulation and irrationality of the masses as possible explanations for this. Yet, recruiting Bourdieu's notion of habitus, Filc suggests an explanation that relies on the former: the inclusion of Mizrahim into Likud created a strong sense of belonging that is rooted in the interaction with the populist movement. A successful project, this identification turned into a habitus, which Bourdieu describes as a "historical product that. . . produces individual and collective practices" (2009, p. 59). Thus, not irrationality, but rather a strong habitus, is at the root of continuous support of the popular sectors of Netanyahu - albeit his neo-liberal agenda. This habitus is wrapped into a new form of populism - post-populism which, according to Filc, represents "continuity and rupture with prior experiences" of inclusive populism. Continuity is preserved on the symbolic field, as the movements' habitus is mobilised to maintain support of the popular classes. Rupture is witnessed in both the material (economic policies) and political spheres (masses are excluded from the political sphere) as a neoliberal agenda is promoted heavily - excluding the very supporters of the group (p.

The habitus, maintained by the symbolic face of populism, is the one assuring continuous support. Netanyahu kept the inclusive rhetoric toward Mizrahim, yet, unlike Begin, employed "exclusionary ethnic nationalism", stressing, amongst others, that Israel's Arabs pose the real demographic danger to Israel (Alon \& Ben, 2003) or even a threat to national security (Filc, p. 72) and anti-elite sentiment. Both latter examples fall into place with Smooha's (2002) conditions for ethnic democracy - an existence of a threat and a manageable size of the minority (p. 479).

Netanyahu's exclusionary populism also includes strong anti-elite sentiments, preserving the populist notion of the pure people vs. corrupt elites (Mudde, 2011). Namely, he positions the left and the media elites as ones that are outside of the 'true Jewish people' representing "them, the enemy, the Arabs and the left" (Filc, p. 72). This strongly resonates with widely used populism theory, as "Populists characterize . . . as enemies of the leader, the people, and by extension, the nation" (de la Torre, 2014, p. 80). These have not substituted, but rather overshadowed, the old 'elite' rhetoric of Begin - the remaining institutions of the old regime (before '77) such as unions and public employees.

According to Peri (2004), Netanyahu handles television, the modern substitute for the town square, in a "mastery way" (p. 220) - a strong populist tool recruited in Netanyahu's bids for power, as will be demonstrated in the 2015 elections as well.

As Netanyahu is heading the most right-wing government in Israel's history, this chapter will now demonstrate the salience of this exclusionary pillar of his populism in both the 2009 elections and the current government in power. Putting forward examples from the Likud, while keeping in mind the prominence of far-right parties in the current coalition, it will be examined if this path 
correlates with the notions set by Ram (2003) as to the neo-Zionist/post-Zionist paths and answers the conditions of an Ethnic democracy by Smooha (2002).

\section{2015 Elections - Getting out the Vote with Exclusionary Ethnic Nationalism}

\subsection{9 - Revisited}

Referred to as "a broken and shortened" election (Gerstenfeld, 2011), the 2009 elections in Israel came against the backdrop of the resignation of former prime minister Ehud Olmert on charges of corruption, as well as an escalation into war with Hamas in Gaza at the end of December - Operation Cast Lead.

The latter is important for this examination, as the war with the Palestinian extreme group Hamas, raging for over 3 weeks, fuelled much of the sentiment of this debate. Enjoying wide public support (Channel 2, 2009), the operation was opposed only by the Arab parties and a single Jewish left-wing party, Meretz. Arab-Israeli politicians were vocal in their opposition to the operation, while following a sweeping parliamentary approval of the operation, other political parties reached a consensus to suspend the official elections campaign until ceasefire (Gerstenfeld, 2011, p. 22). Netanyahu and Likud focused their campaign on attacking Kadima leader Tzipi Livni's (Olmert's successor) intention to create a Palestinian state and divide Jerusalem. Following a classic populist notion, Likud positioned Netanyahu as the "candidate of change" going against the "face of status quo" candidate from the currently ruling party (p. 18). Yet, on the exclusionary ethnic nationalism side, Likud and Netanyahu focused on the greater Islamic fundamentalist threat of 'Tehran-Hamastan', as allowed by a then Iran centred debate and the Gaza war (Filc, 2009, p. 72). In these elections, it was the Yisrael Beiteinu party, led by far-right populist (Pedhatzur, 2012; Filc, 2009) Avigdor Lieberman that controlled the exclusionary anti-Arab sentiment of the debate. Under the slogan of "No citizenship without loyalty" (Israel Beiteinu, 2009), Yisrael Beiteinu led the charge to disqualify Israeli-Arab parties due to their "opposition to Israel's existence as a Jewish state" (Bagno, 2011, p. 19-41). In a successful campaign, Arab politicians were depicted as loyal to Hamas who wishes to destroy Israel. The party's attempt to disqualify them from running succeeded in the election committee and was only overturned by the Supreme Court (Glickman, 2009). Lieberman and Netanyahu later joined forces in the 2013 elections, running as a joint party list and securing a government coalition (Novick, 2012).

\subsection{The 2015 Elections}

In 2015, two main events depict the extent to which Likud and Netanyahu employed the exclusionary ethnic nationalism sentiment, playing the symbolic string of post-populism as a main campaign tool. Firstly, widely covered in the press worldwide, was Netanyahu's video published on March 17, 2015:

The right-wing government is in danger. Arab voters are heading to the polling stations in droves. Left-wing NGOs are bringing them in buses. We do not have V-15 [explanation below], we have 8-order [the emergency reserve duty recruitment order for the Israeli military]. Go 
to the polling stations, bring your friends and families - vote Likud, we will close the gap between us and Labor and with your help - with the help of god - we will form a national government that will protect the State of Israel. (Netanyahu, 2015)

V-15 was a non-parliamentary association created for the 2015 elections with the purpose of changing Netanyahu's government and promote voter turnout in the Israeli centre-left. In his statement, Netanyahu uses rhetoric that is both exclusionary towards Israel 's Arab minority - and their 'partners' in the Israeli left, speaking to the connection between their vote and the 'danger' he warns of. Following the elections, on July 26, 2016, Netanyahu issued an apology video, stating his words were directed at a specific political party - and that Israel's Arabs are invited to "take part in our society - in droves" (JPOST, 2016).

Yet, in an extensive analysis of the Likud campaign, political analyst Amit Segal (2016) published an investigative piece telling the story of the last efforts of Likud to 'get out the vote'- where an extensive form of exclusionary nationalism was used. Following focus groups indicating that people will vote Likud if they feel the party will not be able to form a government, and considering old polls predicting a Labour victory, Likud's campaign manager stated "we had to project loss" (Segal, 2016). And indeed, in the very final hours of Election Day, the Likud campaign machine leaped into action promoting one topic alone: the Arabs and their parliamentary power. Bombarding targeted areas in the periphery, as well as underserved neighbourhoods in the big cities, Likud sent over five million text messages. The first read "Bougie [Isaac Hertzog, the Labour party leader] declared he will appoint an Arab minister to the cabinet", connecting the populist contempt to both the Arab minority and their helpful left-wing. Other texts followed a similar tone to Netanyahu's video:

- $\quad$ "The voter turnout in the Arab sector are three times higher"

- $\quad$ "The Arab voters of Beer Sheva [large city in Israel] are voting in droves, don't let them nominate the next government cabinet"

- $\quad$ "Arab world commentator Ehud Yaari on Channel 2 News: Hamas [Palestinian terrorist organization currently controlling the Gaza strip] is calling Israel's Arabs to go out and vote"

As the effort continued, voter turnout rose dramatically to almost three times more than the equivalent time in the 2013 elections $(6-10 \mathrm{pm})-600$ thousand people went out to vote, with their "crucial majority" (Segal, 2016) voting Likud. Actual low voter turnout in the Arab sector (Starkman, 2015) did not deter Likud from issuing these warnings - with voter statistics for Likud in the last hours showing how powerful this tool is. Revisiting the habitus notion of Likud, one that Filc (2009) credits as preserving the traditional vote for the party, statistics show that this Habitus is preserved in a comparative look of 2009, 2013 and 2015 elections. While in the centre-left there are many fluctuations between parties, the right-wing block remains fairly steady throughout elections, witnessing major changes only when running with Yisrael Beiteinu in 2013 (Kenig, 2015). Reflecting on the 2015 elections, it is evident that ethnic nationalism played a major role in the last effort of Likud to ensure its victory. Keeping in mind the exclusionary nature of symbolic post-populism, and through the lens of Smooha (2002), the connection between the local minority and external threat (Hamas in Gaza) was one tool used, as well as strengthened political 
power of the minority. Moreover, these two together follow the neo-Zionist path set by Ram (2003), as this rhetoric strengthens the ethno-national face of the state for the purpose of gaining political power in the elections.

Finally, events of exclusionary ethnic rhetoric, as well as other postpopulist attributes, dotted the election campaigns. In a 'get out the vote' event, Miri Regev, the most powerful woman in the Likud party (positioned 5th on the party's list for parliament in 2015) depicted Arab MP's as "Trojan horses", using this metaphor to depict them as dangers threatening to ruin the structure from within, as the Greeks did in the city of Troy (Dover, 2015). In addition, resonating Filc's notion of a post-populist leader substituting the square for the television screen, Netanyahu's 'media blitz' of the last week of the campaign, entailing over forty interviews, was surprising as he gave only a small number of these in the years prior to the elections. Through this, Netanyahu managed to "reconnect" to a vast majority of the public and position himself as 'approachable' (Segal \& Levi, 2015).

\section{Netanyahu's Fourth Government}

Sworn in on a thin majority in May 2015, and expanded the following year, the current Israeli government is comprised of all Israeli right-wing political parties and has repeatedly been described as the "most rightwing nationalist government in the country's history" (Beaumont, 2016). Identified as both populist and radical-right (Filc, 2009; Pedahzur, 2012), key positions such as defence, education and justice were handed to Yisrael Beiteinu and the Jewish Home parties, with the former appointment described by the New York Times editorial as "A baffling, hard-line choice" (The editorial board, 2016).

It is in this environment that debates and policies described next unfolded. It is important to stress that the following events are focused on Likud's party, while keeping in mind the effects of the far-right coalition composition on these. Competing for the leadership of the Israeli right, Netanyahu sees Naftali Bennet (head of the Jewish Home religious-nationalist party) as a political threat (Mualem, 2017). Pedahzur, in his explanation of the success of the radical right in Israel and worldwide, claims that more moderate parties have the interest to promote radical right policies as they reap the benefits of promoting popular policy while preventing far-right parties from gaining political capital (2012, p. 9). This can be described as the case in the following events.

\subsection{Basic Law Proposal: Israel as the Nation-State of the Jewish People}

Unable to comprise a constitution during its first term, the Knesset (Israeli parliament) resorted to legislating basic laws with the long-term purpose of binding them together, with necessary additions, into an eventual Israeli constitution. Current laws touch upon state institutions as well as human rights. The superiority of such laws is a matter for difference of opinion - with some saying they are not more powerful than other laws while others stressing the constituent nature of the laws as rendering them more important (The Knesset, N.D.).

A basic law which attracted much attention in Israel is the one 
promoted by Avi Dichter of the Likud party: 'Basic law proposal: Israel as the Nation-State of the Jewish people'. The incarnation of the proposal goes back to the 18th Knesset (2011): put forward by Dichter and Zeev Elkin (the latter is a prominent Likud member, current government minister and formally the chairman of the coalition), it was prevented from being promoted by centreleft fractions of the government. A manifestation of exclusionary ethnic nationalism, the initial proposal included a clause that stresses the subordination of democracy to the state's Jewish character, only includes its democratic character in the second clause - and cancels the status of the Arabic language as an official language of the state (Lis, 2013). With Dichter's initial version disputed, Yariv Levin (yet another current Likud minister and former chairman of the coalition) and Ayelet Shaked (Jewish Home party MP and current Minister of Justice) offered a 'softened' version: the clause cancelling the official status of the Arab language was dropped, an addition was made to stress the importance of preserving the private rights of all citizens - yet still cemented the right of the Jewish people over the land of Israel as superior to any other ethnic group. Causing deep divides in the centreleft-right coalition at the time, both versions were approved by the government ministers in a vote, yet did not arrive for parliamentary discussion before the 2015 elections (Baruch, 2014).

The current version of the law, approved by the Ministers Committee on Legislation on May 7, 2017, is a revised version of Dichter's original proposal from 2011. It stresses Israel as the national home of the Jewish people, determines that "the right for self-determination in the State of Israel is unique to the Jewish people" and revokes the Arabic language's official status determining it to be one of a "special status" (Liel, 2017; Greenberg, 2017). This is a crucial step of the legislation process, essentially 'green lighting' the process.

Coming with an attached promise for a renewed version to be brought forward in two months (Lis, 2017) Netanyahu was extensively vocal in his support for the bill referring to it as "one of the most important laws that any Knesset has ever passed" and expecting "all Zionist parties" to support this "effort led by Likud" (Baruch, 2017).

This legislation received great opposition from the Israeli left, the Israeli moderate right, the EU and the broader international community, with left-wing Meretz party leader Zehava Galon referring to it as a "declaration of war against the Arab citizens of Israel and the democratic Israeli society" (Lis, 2017). In a letter addressed to the Ministers Committee on Legislation, the heads of the Israeli Democracy Institute (IDI) heavily criticised the proposal, calling upon the ministers not to approve it. Warning that the proposal might disrupt the fine balance between the Jewish and Democratic character of the state, the authors warn that the law may have legal repercussions which cements Jewish identity's supremacy in Israeli law - thus hurting the Arab minority in Israel not only symbolically, but in a substantial manner. They state that potential damage to Jewish-Arab relations in Israel may be "irreversible", perhaps turning the state to an "intolerable" place for any Jewish-liberal ideologues (Kremnitzer \& Fuchs, 2017). Keeping in mind Pedahzur's (2012) point regarding the far-right influence on more moderate parties, Mualem (2017) echoes Netanyahu's actions as correlating with exclusionary post-populism. Netanyahu, competing with the far-right Bennet, seized the opportunity to promote this exclusionary 
ethnic policy realising it will appease many in the public. By expecting all Zionist parties to support the law, Netanyahu depicts the opposition as non-Zionist rendering them, according to the rhetoric - as outsiders, if not supporters of the 'enemy'. He also stresses Likud's major role in the efforts, preserving the symbolic pillar of the party through this rhetoric and action (Filc, 2009).

As stressed in the aforementioned IDI letter, even the softened version of the nation-state law disrupts the fine lines of Israeli democracy, as articulated by Smooha (2002). Ethnic democracy, he stresses, entails a need for balance between the ethnic majority and minorities. In addition to issues, the fine line and assurance of civil rights is crucial for stability and for the conservation of a vibrant democratic culture. Moreover, this legislation continues down Ram's (2003) described neo-Zionist path, tipping the scale toward the prevalence of the Jewish over the democratic character of Israel aiming the arrows at the very core of constitutional legislation in Israel.

\subsection{The NGO Bill}

The story of the NGO bill, although initiated by a legislative proposal of the religious-nationalist Jewish Home party, illustrates the atmosphere fostered against NGOs and Human Rights organizations, a majority of which are leftwing oriented. Moreover, the incarnation of this anti-left rhetoric has enjoyed wide support from the Likud party and its leader - and has recently taken on a more extreme rhetoric and action coming directly from Likud. Proposing the law on behalf of the government was Justice Minister Ayelet Shaked of the Jewish Home party (Greenberg, 2013). Fully backed by Netanyahu (Lis, 2016; Beaumont, 2016), the law requires NGOs receiving over half of their funding from foreign governments to state this in reports and official publications, produce a list of all donors - as well as register as such and threatens a high fine if they fail to do so. Dropped from the final approved version, the original proposal also required NGO representatives that answer the latter criteria to wear identification tags, that the law be implemented retroactively and that private donations be regulated (Lis, 2016). Ostensibly preserving state sovereignty and promoting transparency, the law has been criticised as aimed directly at left-wing and Human Rights NGOs, although it does not state so specifically and its supporters have denied this repeatedly. Yet, an official list produced by the registrar of non-profit organization in the Justice Ministry, a list which the Jewish Home chairman of the committee discussing the law refused to disclose to committee members, shows 25 out of 27 affected NGOs are either left-wing or Human Rights centred. Though including organizations such as the Hotline for Refugees and Migrants, this list uncovers a possible left-wing NGO targeting intention behind the bill, and correlates with the post-populist symbolic exclusion of left-wing activity (Filc, 2009; Lis, 2016; Times of Israel, 2016). Similar right-wing NGOs receive most support from private donations and are thus not affected by the law.

Following a heated debate and fierce opposition, Netanyahu congratulated the legislation passing in parliament stating "Unlike the left's claims, the law's approval will increase transparency, contribute to creating a discourse that reflects the Israeli public opinion, and will strengthen democracy" (Beaumont, 2016), calling foreign donations an "absurd" intervention. Opposition leaders opposed the Law, blaming the government for silencing criticism and actively persecuting Human Rights groups. The Association for Civil Rights in Israel claimed the law constitutes "political persecution of specific 
NGOs aimed at marking them with a badge of shame" (ACRI, 2016). The international community also strongly denounced it. The EU, its member states donating most of the funds discussed in the law, stated the law "go[es] beyond the legitimate need for transparency and seem[s] aimed at constraining the activities of these civil society organizations", adding that considering Israel's vibrant democracy and diverse civil society, the legislation "risks undermining these values" (Baker, 2016). UN Secretary General, Ban Ki-moon, said he is "deeply troubled" as he is worried this law will contribute "to a climate in which the activities of human rights organizations are increasingly delegitimized" (Harkov, 2016).

Two left-wing organizations affected by the NGO bill, B'Tselem and Breaking the Silence, devote their efforts to working against the occupation of the Palestinian territories, in Israel's control since the 1967 war - an issue perhaps constituting the most heated political cleavage in Israeli politics. Both were harshly denounced in recent years by the Israeli right wing, with the Likud and Netanyahu reaping political gain while employing strong exclusionary rhetoric, following post-populist features. It is important to stress that general criticism, as well as fierce opposition to the activity of these groups is not criticised across the board. Yet, it is the following described rhetoric and actions against the groups that cause some concern. In April 2017, Netanyahu cancelled an official meeting with German Foreign Minister, Sigmar Gabriel, after the latter was scheduled to meet representatives of both B'Tselem and Breaking the Silence during an official visit to the region (Ravid \& Aderet, 2017), similar to meetings conducted by foreign leaders before. This move was described by Netanyahu as "firm foreign policy" to be enacted with all foreign countries. The German minister refused to take Netanyahu's call following the cancellation and Netanyahu suffered criticism for the move (Levinson, 2017). Recently, a formal spokesman of the German foreign ministry compared Israel's treatment of NGO's receiving funds from foreign countries to that endured by NGO's in China or Russia (Ravid, 2017).

Following a series of inflammatory discourse around these organizations, constantly depicting them as 'collaborators of the other', Likud's Tzipi Hotobeli, acting as Deputy Foreign Minister (under Netanyahu, the acting Foreign Minister) referred to these organizations as fifth columns. Speaking of Breaking the Silence, she said: "Our wars are just, and in all these wars we face one enemy called Hamas and a second enemy that is those organizations ... an enemy that harms Israel. Unequivocally" (Haaretz, 2017). This rhetoric, led by top government representatives, joins the general anti-left discourse. Amongst others, left-wing groups' leaders were depicted as 'Moles who are fighting us' and activists were attacked in a joint Israeli-Palestinian peace demonstration (Pulwer, 2015; Liel, 2017).

Taking the lead in a meeting of coalition party leaders, Netanyahu declared he will be promoting a new, tougher version of the NGO bill which would completely ban Israeli NGOs from receiving funds from any foreign governments, tasking Minister Yariv Levin (known for his struggle against the Supreme Court which he depicts as a "branch of the Israeli left") (Azulay, 2017). A significant exacerbation of the scope of possible harm to NGOs relying on these funds, the law entails grave diplomatic and legal constraints: it may target predominantly left-wing organizations and will be tough to defend in the Supreme

Court. 
Moreover, as Netanyahu was the one behind softening the initial law, it is interesting to see this leap to the right. In what seems as another attempt to appease far-right voters and party hardliners, liberal political commentator Yossi Verter notes that the new legislation offered by Netanyahu comes as push-back to Jewish Home Education Minister Naftali Bennet's moves to curb political discourse in Universities - stating "Bennet's trick made Netanyahu produce an adequate nationalistic response" (2017). Resonating Pedahzur once again, a shift to the far-right in order to preserve political support for Likud and Netanyahu seems a reasonable explanation for these moves (2012).

From declaring the necessity of the nation-state law to exacerbating the moves against left-wing activism in the country, Netanyahu continues to employ strong exclusionary policies and rhetoric against minorities and political opposition. Repeatedly drawing the connection between Israel's enemies (i.e. Hamas), Israel's Arab minority and Israel's left, Netanyahu follows Smooha's (2002) ethnic democracy theory, preserving a constant sense of threat. Making the connection between enemies, ethnic minorities and a 'collaborative' left, Netanyahu constantly worsens the sense of exclusion of the two latter groups - preserving his support at the expense of others (Filc, 2009). Moreover, this direct assault on Israeli civil society, one that seems aimed at the Israeli left more than anyone else, follows the neo-Zionist path described by Ram (2003), as rhetoric and policies actively erode Israel's civil society to make room for more Jewish national sentiment. What seems to be a work in progress, this path entails the danger of creating a strong chilling effect on opposition and civil society, as legislative moves as the ones surveyed can be viewed as a threat to the very legitimacy of their actions.

\section{Conclusion}

When examining Netanyahu as a post-populist leader, there is a need to take a broader look at the different pillars comprising this strand of leadership. Though the material and political pillars, characterised by neo-liberal economic policies, are depicted as highly exclusionary to those who have continuously supported the Likud party - the popular vote - the symbolic pillar preserves the habitus of the Likud party and its leader by building on its historic inclusionary sentiment - granting Likud unprecedented political success in Israel. Yet, the symbolic pillar, though depicted as the remaining inclusive one - gains this title while inherently promoting exclusionary rhetoric - namely the ethnic-nationalistic one, assuring the creation of a constant threat from the 'other' as a means to preserve the habitus. As seen through the examination of the aforementioned events, this rhetoric has long been translated into active policies promoted by the government, constituting material effect on groups such as the Israeli Arab minority and the Israeli left-wing and civil society.

Taking a broader look on discussions of populism, it is possible to employ a number of similarities to position post-populism in the greater debate. Relying on the inclusive/exclusionary discussion on populism articulated by Filc (2009), Mudde and Kaltwasser (2013) compared European and Latin American populism - with the latter featuring leaders also depicted by Filc as postpopulists. For his comparison, Mudde uses a minimal definition of populism as a "thin-centered ideology" separating society between 'the pure people' and 'the corrupt elite' - advocating the former's right for power (as cited in Mudde, 
2012 , p. 150). Pairing this with the inclusive and exclusionary forms of populism explained in this chapter, it is possible to examine populist manifestations through this prism. It is already concluded that Likud's populist tradition started as inclusive, similar to Latin American populism, but is now depicted as postpopulism due to its exclusionary neo-liberal expressions. Mudde concludes that right-wing European populism is structured primarily around socio-cultural issues (identity politics) while Latin American is socioeconomic centred. This is explained by the economic and political development of these areas, allowing the two issues to thrive considering the situation on the ground. In turn, European populism "mainly focuses on the exclusion of non-native groups" as the Latin American populism focuses on inclusion of "socioeconomic deprived groups"

166).

Turning to Netanyahu from the latter point, although described as a post-populist similar to some Latin American leaders, the focus of this chapter showed how vastly Netanyahu uses the exclusionary symbolic tool in his populist style. As can be derived from Smooha's (2002) ethnic-democracy, the very core of Israeli politics is intertwined with identity politics - and alongside Israel's successful economic development - it is not surprising to find similarities between Israeli and European right-wing populism in the sphere of exclusionary ethnic rhetoric.

When attempting to position Netanyahu's post populism in the greater map of populist sentiment and leadership worldwide, it can be generally concluded that there is more of the same being employed, with minor changes allowing more or less success for some leaders in the populist sphere. While similarities and differences to other populist movements and leaders are varied, the focus of this chapter resonates almost across the board when referring to right-wing populism in the west. Though stemming from various sentiments, political realities and anxieties, the underlying common feature of these movements has recurrently been the extensive use of fear mongering to gain support. Xenophobic, racist and anti-minority sentiment - as well as the depiction of left-wing liberals as collaborators and elitist - has fuelled the masses in many countries. Donald Trump in the US, with his inflammatory rhetoric against immigrants and Muslims, managed to obtain what is considered the highest office in the Western world. The British people, driven by rhetoric of destructive uncurbed immigration to their nation, chose entrenchment led by a populist nationalistic front. The French, Austrians, Dutch and other people in the west have granted racist-populist leaders great support - and support for populist parties has been constantly on the rise (Inglehart \& Norris, 2017). Netanyahu, in Israel, is close to becoming the country's longest serving prime minister

ever.

Though described as a post-populist, it is possible to transcend over the exclusionary neo-liberal policies led by Netanyahu and recognise the strength of his exclusionary nationalist rhetoric. His choice of words, policies and executers show Netanyahu "spearheads" Israeli populism (Mualem, 2017). By this, and by the described path taken in Israel in recent years, the neoZionist path by which Jewish national-ethnicity is strengthened at the expense of the civil state and liberal values is becoming stronger (Ram, 2003, p. 155). Connecting this chosen path with the delicate fabric of ethnic-democracies, it can be seen that the fine balance between the Jewish and Democratic faces of the state is being shaken by Israel's social cleavages - while minorities and political groups stand in the crossfire. 
Yet, as articulated by Mualem (2017) and shown in this chapter, a major difference in the Israeli right nowadays is the lack of opposition from within. Positioned as the more moderate right, when viewing the coalition from a broad perspective, Likud's old inner-opposition to clearly populist, anti-civil moves is gone. Those who formally played roles in Likud and were still around to defend its long-standing liberal-democratic tradition are no longer in it - and with the far-right enjoying such power positioned to the right of Likud, Pedahzur's (2012) ideas can be witnessed as a form of spill-over effect in the Israeli right in general. Facing a weaker habitus than before, Netanyahu has exacerbated his exclusionary populism to a large extent as a response to the strengthening of far-right parties and sentiment in the general public. By this, the general populist sentiment has gained much ground in Israeli political discourse - with the depictions of the other growing more intrusive and violent than ever before.

While this chapter touched upon the fine balance between Israel's Jewish and Democratic faces, the challenge and urgency of this issue were conveyed by long-time Likud politician and current President of Israel, Rubi Rivlin, speaking in the liberal organised Israel Conference on Peace:

We have to stop eroding the value of the democratic currency ... We are playing with fire. We must stop marking and 'persecuting traitors', stop giving grades on Zionism. We must stop persecuting the State of Israel on different international stages. Why should we not all be respected and explain our positions to the public? Thus, those who favor the partition of the land should explain to the public how Israel can ensure its security. On the other hand, those who favor keeping the territories should explain how Israel can guarantee its democratic identity without compromises and assumptions alongside its Jewish identity . . . as time passes, the decision becomes dearer and more threatening. Let's make sure, that we reach it prepared. (Berger \& Spiegel, 2017) 